\title{
Community based actions save Yellow-spotted river turtle (Podocnemis unifilis) eggs and hatchlings flooded by rapid river level rises
}

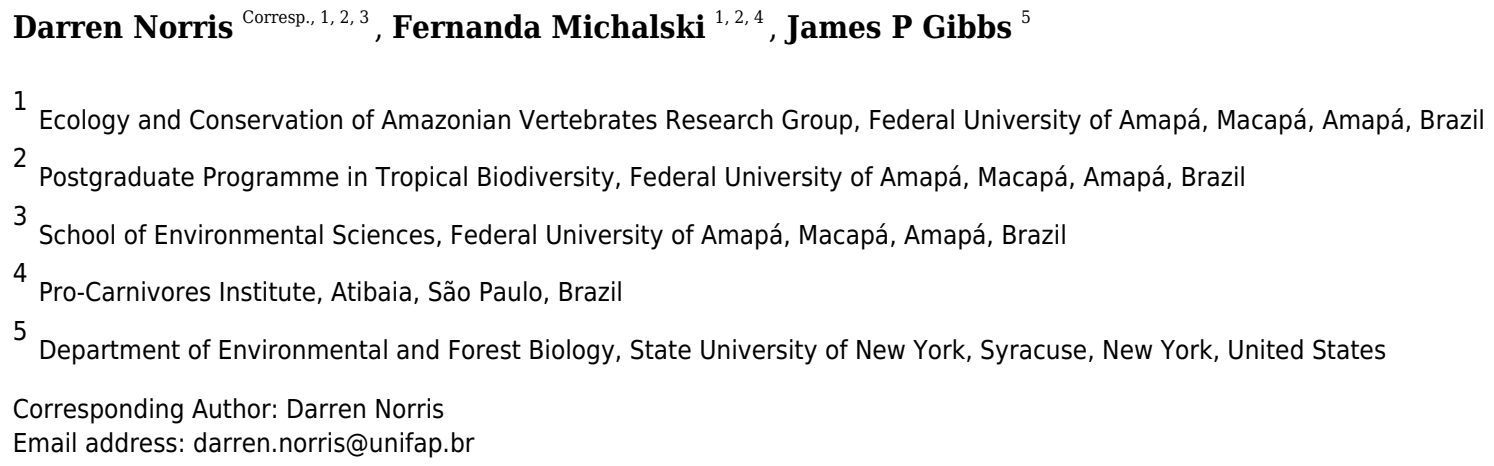

The conservation and recovery of increasingly threatened tropical freshwater turtle populations depends on effective management plans and actions. Here we show that community-based actions saved Yellow-spotted river turtle (Podocnemis unifilis) eggs submerged by unseasonal flooding and ensured the release of hatchlings. We recovered 926 eggs and 65 premature hatchlings from 74 submerged nests at 16 flooded nesting areas along $75 \mathrm{~km}$ of waterways. The rescued eggs were transferred to a rearing center and incubated. Hatchlings emerged from eggs that had remained underwater for up to two days. Hatchlings were maintained in 250 - 500 L nursery tanks until yolk sac scars had closed. Healthy hatchlings were then immediately released around the original nesting areas. We released 599 hatchlings (60.4\%) from 991 submerged eggs and hatchlings. Egg survival [61.7\% (571 / 926)] was substantially less than hatchling survival [94.2\% (599 / 636)] but within the expected range of values reported for this species. These findings suggest that Yellow-spotted river turtle eggs and embryos are resistant to short-term submersion, which could help explain the widespread distribution of this species across highly seasonal Amazonian rivers. Management plans should take the possible survival of submerged eggs into consideration as part of species conservation and recovery actions. 
1 Community based actions save Yellow-spotted river turtle (Podocnemis

2 unifilis) eggs and hatchlings flooded by rapid river level rises

3

4 Darren Norris ${ }^{1,2,3^{*}}$, Fernanda Michalski ${ }^{1,2,4}$ James P. Gibbs ${ }^{5}$

5

$6{ }^{1}$ Ecology and Conservation of Amazonian Vertebrates Research Group, Federal University of

7 Amapá, Macapá, Amapá, Brazil

$8{ }^{2}$ Postgraduate Programme in Tropical Biodiversity, Federal University of Amapá, Macapá, 9 Amapá, Brazil

13 New York, United States

14

* Corresponding author:

Darren Norris ${ }^{1}$

Email: darren.norris@unifap.br

8

19 
21 Abstract

22 The conservation and recovery of increasingly threatened tropical freshwater turtle populations

23 depends on effective management plans and actions. Here we show that community-based

24 actions saved Yellow-spotted river turtle (Podocnemis unifilis) eggs submerged by unseasonal

25 flooding and ensured the release of hatchlings. We recovered 926 eggs and 65 premature

26 hatchlings from 74 submerged nests at 16 flooded nesting areas along $75 \mathrm{~km}$ of waterways. The

27 rescued eggs were transferred to a rearing center and incubated. Hatchlings emerged from eggs

28 that had remained underwater for up to two days. Hatchlings were maintained in $250-500 \mathrm{~L}$

29 nursery tanks until yolk sac scars had closed. Healthy hatchlings were then immediately released

30 around the original nesting areas. We released 599 hatchlings $(60.4 \%)$ from 991 submerged eggs

31 and hatchlings. Egg survival [61.7\% (571/926)] was substantially less than hatchling survival

$32[94.2 \%(599 / 636)]$ but within the expected range of values reported for this species. These

33 findings suggest that Yellow-spotted river turtle eggs and embryos are resistant to short-term

34 submersion, which could help explain the widespread distribution of this species across highly

35 seasonal Amazonian rivers. Management plans should take the possible survival of submerged

36 eggs into consideration as part of species conservation and recovery actions. 
38

39

40

41

42

43

44

\section{Introduction}

Like many tropical species Amazonian freshwater turtles are threatened by deforestation (Fagundes et al. 2018), climate change (Eisemberg et al. 2016), and unsustainable exploitation (Rachmansah et al. 2020; Smith 1979). Precautionary estimates suggest that populations of the once abundant Yellow-spotted river turtle (Podocnemis unifilis) may experience severe ( $\geq 50 \%)$ and rapid ( $<50$ years) future losses across $60 \%\left(5.3 \mathrm{M} \mathrm{km}^{2}\right)$ of the pan-Amazonian range (Norris et al. 2019). The conservation and recovery of this and other Amazonian freshwater turtles will therefore depend on effective and active management plans that are likely to be more successful with local community involvement (Campos-Silva et al. 2018; Harju et al. 2018; Norris et al. 2018b; Norris et al. 2019).

Increasingly frequent alterations in the seasonal Amazon flood pulse may seriously impact the region's flora and fauna (Barichivich et al. 2018; Marengo \& Espinoza 2016). Unpredictable water level rises are known to strongly affect freshwater turtle recruitment along seasonally flooded rivers (Bodie 2001; Semlitsch \& Bodie 2003; Steen et al. 2012). Whilst some turtles show adaptations to predictable changes in water levels (Kennett et al. 1993), extreme flooding events cause dramatic increases in egg and embryo mortality in South American Podocnemididae (Eisemberg et al. 2016; Páez et al. 2015).

Nesting in members of the Podocnemididae is usually synchronized to avoid the seasonal flood pulse in lotic waterways. However, elevated nest loss due to extreme and/or unseasonal flooding has been widely documented in Podocnemis erythrocephala (Batistella \& Vogt 2008), P. expansa (Eisemberg et al. 2016), P. lewyana (Gallego-García \& Castaño-Mora 2008), $P$. sextuberculata (Vogt \& Pezzutti 1999) and P. unifilis (Caputo et al. 2005). The impact of nest 
60 flooding is highly variable in space and time depending on difficult-to-predict factors such as the

61 start of the rainy season and its intensity (Eisemberg et al. 2016). For example, flooding of $P$.

62 unifilis nests caused annual losses of less than 10\% in Brazil (Pignati et al. 2013), 63\% in

63 Ecuador (Caputo et al. 2005), 64\% in Colombia (Páez \& Bock 1998) and 1 to 100\% in Peru

64 (Soini 1995). Thus, although the widespread distribution of these species demonstrate an

65 evolutionary stable adaption to fluctuation of egg and juvenile mortality due to flooding across

66 the decades of female reproduction, rapid river level rises are a major factor affecting turtle nest

67 mortality. Indeed, $21^{\text {st }}$ century changes across Amazonian waterways (Castello et al. 2013) are

68 driving increasing mortality across the species' ranges (Lovich et al. 2018; Páez et al. 2015;

69 Rhodin et al. 2018).

Although the biology of and threats to P. unifilis are well documented, there is still limited evidence of the efficacy of different management options for conservation of P. unifilis (Páez et al. 2015). Increased population losses are expected due to widespread and abrupt alterations in river flow patterns caused by climate change, habitat loss and hydroelectric expansion (Castello et al. 2013; Eisemberg et al. 2016; Fagundes et al. 2018). Indeed, dams present a unique challenge to freshwater turtles in the area of reservoir formations due to irreversible submersion of nesting areas (Alho 2011; Lees et al. 2016; Norris et al. 2018a). Yet, we lack solutions to the known impacts of submersion on $P$. unifilis nest sites.

Here we present the results from community based recovery of $P$. unifilis eggs and premature hatchlings submerged by unprecedented rapid river level rises. We ask how many of the flooded eggs remain viable and if hatchlings were apparently healthy. We use our results to discuss how management plans could include rescue of submerged eggs and premature hatchlings as part of species conservation and recovery actions. 
84

85

\section{Methods}

\section{Ethics statement}

All methods were carried out in accordance with relevant guidelines and regulations. The actions we report were developed and applied following international (Beaupre et al. 2004) and national (Balestra 2016) guidelines. Fieldwork and data collection were conducted under research permit numbers SISBIO 63668-1 and 63668-2 to DN, issued by the Brazilian Ministério do Meio Ambiente ("MMA"). Fieldwork with turtles was approved by the Animal Use Ethics Committee from the Federal University of Amapá (UNIFAP) (CEUA-UNIFAP approval 009/2017).

\section{Study area}

The study was conducted in the Araguari river basin, located in the Brazilian State of Amapá (Fig. 1). Nesting of Podocnemis unifilis has been monitored since 2011 in the study area and here we present a brief summary of the previously described study area and P. unifilis nesting areas (Michalski et al. 2020; Norris \& Michalski 2013; Norris et al. 2018a; Norris et al. 2018b;

Quintana et al. 2019). Climate in the area is characterized as equatorial monsoon (Kottek et al. 2006) with an annual rainfall greater than $2000 \mathrm{~mm}$. Rainfall is strongly seasonal, with the dry season extending between September and November (total monthly rainfall $<150 \mathrm{~mm}$ ), and the wet season from February to April [total monthly rainfall $>300 \mathrm{~mm}$ (de Oliveira et al. 2015; Paredes et al. 2017)]. 


\section{Data collection}

105

106

107

108

109

110

111

112

113

114

115

116

117

118

119

120

121

122

123

124

125

As part of a collaborative monitoring scheme with the local community, we monitored $29 P$. unifilis nesting areas from September to December 2018. This is a representative subset of the available nesting areas described previously (Norris et al. 2018a; Quintana et al. 2019) that were chosen in 2018 to encompass broad gradients (environmental and anthropogenic) and include areas with the majority of nests (including nesting areas with $>90 \%$ nests recorded in previous years). Nesting areas were visited at least once a month to search for turtle nests and to monitor conditions of nests that were individually marked with a small stick. Nests were located by following turtle tracks on the sandy/gravel substrates and systematic substrate searches with blunt wooden sticks and fingertips (Escalona \& Fa 1998; Norris et al. 2018a; Quintana et al. 2019). Searches were conducted by teams of two to three observers along lengthwise transects throughout each area at a standardized speed (mean 0.8 , range $0.2-1.3 \mathrm{~km}$ per hour); time spent searching nesting areas ranged from 10 to 97 minutes depending on the size of the area (Norris et al. 2018a).

\section{Recovery of submerged eggs}

In 2018, the work with local communities could be classified as collaborative monitoring with external data interpretation (Danielsen et al. 2009). In addition to monitoring nesting areas, members of the local communities also participated in management actions including installation and monitoring of nest predator exclusion devices (Norris et al. 2018b). Previously, strategically targeted community-based actions at only two nesting areas enabled the successful protection of $75 \%$ of nests along a $33 \mathrm{~km}$ stretch of river (Norris et al. 2018b). In 2018 actions were expanded 
126 to include two monitoring teams working simultaneously (one team on each of the Araguari and 127 Falsino rivers).

In 2018 there was an unprecedented and rapid rise in river levels (Fig. 2). On the 29

129 November 2018 the field team from the Falsino river reported rising river levels due to

130 unseasonal early rains and that on 28 November some nests had been moved to higher points on

131 at least one nesting area. Based on our knowledge from previous years in the region there was no

132 expectation that the river water level would continue to rise. However, after assessing the river

133 level at the field site on 30 November it became clear that the rapid water level rise was flooding

134 nests along both Araguari and Falsino rivers. Members of the local community living in the

135 region for more than 30 years remember early rain, but do not recall river levels rising so

136 quickly. Hence, as this was an unprecedented event, our team took action to try and save at least

137 some of the nests.

138 To reduce the loss of eggs and hatchlings our plan of action followed these steps (Fig. 3):

139 1) Move nests to higher locations that would not be flooded keeping them in the same

140 nesting area where eggs were laid.

141 2) Locate and collect submerged eggs and hatchlings where possible.

142 3) Transport and dry sand from the nesting beaches (needed for incubating eggs and

143 strengthening of hatchlings).

4) Set up incubators for eggs.

5) Transfer hatchlings to a "nursery" for strengthening.

6) Release hatchlings in the same region where they were rescued. 
By 1 December 2018 it was clear that the river levels would not decline and that we would need to take additional steps (i.e. moving nests to higher points within the same nest site was no longer a viable option). We established an improvised rearing facility located on the property of a local landowner. We created incubators for eggs and temporary nursery tanks for premature hatchlings. Eggs were placed in incubators $(50-80$ liter polystyrene foam boxes) filled with sand from the submerged beaches and heated by lamps with the aid of a generator that was turned on at least four hours a day (Fig. 3). Hatchlings were transferred to water tanks (250 or 500 liter) that served as nursery areas for strengthening and to enable complete absorption of the yolk sac (Fig. 3). In the nursery tanks fresh vegetation [cassava (Manihot esculenta) leaves] was also provided for both food and shelter. Hatchlings were periodically (every 2-3 days) weighed and measured (straight-line carapace length and width) to monitor their health and development.

Hatchlings were released when umbilical scars were closed. Prior to release hatchlings were examined for any external sign of disease (i.e., fungus, botfly larvae) and weighed. Although all hatchlings were examined, due to logistical difficulties it was not always possible to weigh hatchlings prior to release. We were able to weigh $409(68 \%)$ of the 599 released hatchlings (145 and 264 from Araguari and Falsino rivers, respectively). Healthy hatchlings were then released close to the original nesting area. By the time of hatchling release (up to 1 month after rescue) all nesting areas had been flooded and were totally submerged. We therefore selected release areas that were upstream and close (within $200 \mathrm{~m}$ ) to the original nesting areas with relatively calm water and access to shelter and food along the river banks (i.e., small perennial streams that join the main rivers). 


\section{Data analysis}

171 All statistical analysis and graphics production were undertaken within the R language and

172 environment for statistical computing (R Development Core Team 2020). One-way Analysis of

173 Variance (ANOVA) was used to test for differences in body mass and condition between

174 hatchlings from Araguari and Falsino rivers. We calculated two body condition indexes for

175 released hatchlings to evaluate the relative condition on the day they were released. The indexes

176 were obtained from the residuals of Generalized Additive Models [GAMs, (Wood 2011; Wood

177 2017)] of the response of $\ln$ transformed body mass predicted separately by $\ln$ transformed

178 straight-line carapace length and $\ln$ transformed carapace area. The carapace area $\left(\mathrm{cm}^{2}\right)$ was

179 calculated as an ellipse by standard formula from the radius of the major (ra) and minor (rb) axis

180 (expressed in $\mathrm{cm}$ ) as follows:

We used GAMs to avoid known problems of residual body condition indexes obtained

183

184

185

186 187 2001; Peig \& Green 2010).

from linear (ordinary least square) regression, namely the assumption that mass and body size relationships are linear (Green 2001). GAMs include non-parametric smooth terms and are able to model non-linear relationships (Wood 2011) such as those expected between mass and body size (length or area) as body size changes and growth (a multiplicative process) occurs (Green

\section{Results}


190 The river water level rose 2.2 meters (from $343 \mathrm{~cm}$ to $561 \mathrm{~cm}$ ) over 16 days between 24

191 November and 10 December 2018 (Fig 2). On average P. unifilis nests were laid at a height

192 equivalent to the river level of $472 \mathrm{~cm}$ (Fig 2). The highest nests were laid at $526 \mathrm{~cm}$, which

193 means that $100 \%$ of nests would have been entirely submerged by 8 December (Figure 2 ). Eggs

194 and premature hatchlings were recovered from a total of 74 submerged nests in 16 nesting areas

195 along $74.6 \mathrm{~km}$ of rivers (Table 1). On average nests were laid at similar heights above the water

196 along both rivers (Table 1), but submerged nests were detected and recovered earlier along the

197 Araguari river (between 30 November and 2 December) compared with the Falsino river

198 (between 1 and 5 December), which had the highest nesting areas with nests laid $69 \mathrm{~cm}$ above

199 the maximum height on the Araguari river (Table 1).

Nests were submerged for 0 to 2 days (Table 1). Premature hatchlings were only recovered

201 alive from waterlogged nests that had water infiltrating from below (i.e. 0 days submerged).

202 Eggs were recovered from nests that were waterlogged ( 0 days submerged) to two days

203 submerged. At the time of recovery the depth of water ranged between 0.05 to 1.30 meters above

204 the nests. The overall survival rate of eggs and pre-mature hatchlings was $60.4 \%$, with 599

205 hatchlings released from 991 eggs and pre-mature hatchlings (Table 2). A total of 582 hatchlings

206 emerged from 926 eggs that had been submerged for up to 2 days. Hatchling emerged more than

207 a month after submersion, with the last hatchlings emerging on 10 January 2019 (36 to 40 days

208 after recovery). The vast majority (94.2\%) of emerged and pre-mature hatchlings survived (Table

209 2) and all surviving hatchlings were released by 31 January 2019.

211 Although mean body mass was significantly greater for hatchlings released on the Falsino river

212 (Table 2, one-way ANOVA, $\mathrm{F}_{1,407}=8.00, P=0.005$ ), the increase of $0.6 \mathrm{~g}$ compared with body 
213 mass of Araguari hatchlings represented only 3\% of the mean body mass $(18.0 \mathrm{~g})$ from all

214 released hatchlings (Table 2). The relationships between $\ln$ transformed body mass and $\ln$

215 transformed body size (carapace length and area) were not linear [Fig 4, GAM effective degrees

216 of freedom $(\mathrm{EDF})=5.5$ and 7.1 for straight-line carapace length and carapace area respectively].

217 The body condition index values ranged from -0.15 to 0.08 and -0.36 to 0.26 from the straight-

218 line carapace length and carapace area models respectively (Fig 4). Hatchling body condition

219 increased slightly in Falsino hatchlings (Fig 4). Body condition based on ln straight-line carapace

220 length differed weakly between rivers (one-way ANOVA, $\mathrm{F}_{1,407}=5.51, P=0.019$ ) and a similar

221 pattern was found with the residual body condition index derived from $\ln$ carapace area (one-way

222 ANOVA, $\left.\mathrm{F}_{1,407}=11.47, P=0.0008\right)$. Although statistically significant, there were only small

223 differences in mean condition index values between rivers [Araguari $(-0.008,-0.011)$ and

224 Falsino $(0.004,0.006)$, mean values from straight-line carapace length and carapace area models

225 respectively] and the distributions of body condition values were also similar (Fig 4).

226 Additionally, the interquartile range of body condition index values for hatchlings from both

227 rivers overlapped zero (Fig 4).

229 Discussion

230

To our knowledge we demonstrate for the first time that P. unifilis embryos are resistant to

short-term submersion. We also show that healthy hatchlings survived and were successfully

232

released following egg submersion. Early stages of freshwater turtles are known to suffer

233 elevated mortality (Iverson 1991). The mortality of $P$. unifilis eggs and hatchlings is usually

234 elevated and varies widely, typically with $60-100 \%$ mortality in natural settings (Caputo et al. 
235 2005; Escalona \& Fa 1998; Ferreira Júnior \& Castro 2010). Additionally, previous studies show

236 that human harvest is also a major cause of nest loss in our area (Norris et al. 2018b; Quintana et

237 al. 2019). As such the release of hatchlings from over half of the submerged eggs (that would

238 otherwise have suffered $100 \%$ loss) is within the expected survival of natural nests.

239 The average body mass $(18.0 \mathrm{~g})$ of released hatchlings was similar to values reported

240 elsewhere for this species. Previous studies report mean hatchling weights of 17.8 to $20.0 \mathrm{~g}$ in

241 Colombia (Páez \& Bock 2004), $17.3 \mathrm{~g}$ in Ecuador (Caputo et al. 2005) and $20.8 \mathrm{~g}$ from

242 hatchlings $(\mathrm{n}=99)$ along the Falsino River in 2011 (Arraes 2012). Although we obtained

243 statistical differences in body mass between hatchlings from Araguari and Falsino rivers, such a

244 small difference $(0.6 \mathrm{~g})$ is unlikely to be biologically relevant. We were unable to monitor the

245 long-term survival of the released hatchlings; however, there is no reason to expect that they

246 would experience any negative impacts of short-term rearing. We believe that we effectively

247 reduced known issues of captive rearing (Burke 2015) by maintaining hatchlings at low densities

248 and for a short period of time.

Different eggshell types may provide different levels of protection to embryos (Deeming

251 short-term submersion (Packard et al. 1982; Winkler 2006). Although P. unifilis eggs are rigid,

252 the shells remain somewhat permeable, for example allowing passage of agro-toxins (Hirano et

253 al. 2019). Yet P. unifilis eggshells have a low pore density (Winkler 2006; Winkler \& Sánchez-

254 Villagra 2006), which is likely to limit exchange of water with the environment (Packard et al. 255 1982). 
Although rigid eggshells can resist hydric changes, embryos are susceptible to changes in

257

258 temperature associated with submersion. As $P$. unifilis only occurs within the tropics (Norris et al. 2019; Rachmansah et al. 2020), temperature is likely to be a key determinant for the survival of all stages and it is unlikely that embryos have any adaptation to resist low temperatures such as those experienced under flowing rivers. The temperature range for successful incubation of $P$. unifilis nests is typically between $27-32^{\circ} \mathrm{C}$ (de Souza \& Vogt 1994; Ferreira Júnior \& Castro 2006; Páez \& Bock 1998; Páez \& Bock 2004). Although temperature dependent sex determination has been well studied in P. unifilis (de Souza \& Vogt 1994), other aspects such as embryo survival in relation to temperature remain poorly investigated. For example in the pivotal study for the species, de Souza \& Vogt (1994) state "there was high mortality among the eggs switched from $34 \mathrm{C}$ to $28 \mathrm{C}$ ", providing no information on when the change was made or quantity (n or \%) that died.

Intervening to prevent losses is often a necessary component of wildlife conservation projects. Yet, there are ethical and moral concerns associated with these actions. Turtles can be considered a special case in several ways. All turtles are oviparous and P. unifilis do not provide any post-oviposition parental care, therefore, no surrogates for parental care and training are needed to rear eggs and hatchlings (Burke 2015). Indeed rearing P. unifilis hatchlings has become an integral part of management approaches across the species range (Harju et al. 2018; Páez et al. 2015; Sinovas et al. 2017). We took reasonable precautions to address ethical concerns, including providing appropriate temperature, water and food (reflected in the increase in body weight), avoiding risks of disease spread from exotic species, and ensuring that premature hatchlings were retained for the minimal time necessary before release to the wild. We suggest that the improvised response to unprecedented river level rise was appropriate and 
279 provided a positive contribution to the conservation of $P$. unifilis populations along the rivers.

280 Continued long-term monitoring is required to establish if such interventions enable freshwater

281 turtle populations to persist and even recover across Amazonian rivers increasingly impacted by

282 anthropogenic harvests (Norris et al. 2019) and flow-rate alterations (Castello et al. 2013).

Considering the drastic changes to Amazonian river flow regimes it seems reasonable for management actions to include contingency plans for recovery and release of submerged $P$. unifilis eggs and hatchlings. A total of US \$5007 was spent (exchange rate of 3.78 Brazilian R\$ to 1 US\$, food, gasoline, daily stipends, rearing equipment) during the two month improvised rearing process (28 November 2018 - 31 January 2019, Fig 3), representing an overall financial investment of US\$8.36 for each $P$. unifilis hatchling released. In comparison, the community based monitoring implemented with two teams required on average US\$2302 per month (food, gasoline, daily stipends) i.e. US\$4604 over a two month period. Therefore improvised rearing does not necessarily represent an excessive financial investment beyond that expected as part of the actions for conservation and monitoring of the species.

\section{Conclusion}

The resistance of $P$. unifilis eggs and embryos to short-term submersion could help explain their widespread distribution across tropical South America. The continued decline of the species across its range shows that such adaptations are insufficient to respond to unprecedented $21^{\text {st }}$ century changes across riverine habitats. Our successful rescue of eggs and premature hatchlings from flooded nests and subsequent release of healthy hatchlings demonstrates the viability of recovery actions. Such actions are likely to be increasingly necessary across rivers where not 
301 only are flow rates affected by damming but also anthropogenic harvests can drive unsustainable 302 harvests of turtle nests. We suggest that such recovery actions should be included in action plans 303 for species conservation and recovery. Additionally, hydroelectric developments should evaluate 304 localized changes in flow rates to avoid seasonal flooding of nesting areas and pro-actively avoid 305 the need for recovery actions. 
307 Acknowledgements

308 The Instituto Chico Mendes de Conservação da Biodiversidade (ICMBIO) and the Universidade

309 Federal do Amapá provided logistical support. We are grateful to Manuel Justino de Abreu,

310 Fabio Cardoso de Abreu, Cremilson and Cledinando Alves Marques, Raimundo Marques,

311 Alvino Pantoja Leal, Arlete Pantoja Leal and Gilberto Souza for their invaluable assistance

312 during fieldwork. We also thank the volunteer interns who aided in nest area monitoring and egg

313 and hatchling rearing. This study is dedicated to the memory of Elma Palleta Normandia

314 Marques.

315

316

Peer) reviewing PDF | (2020:05:49421:2:0:NEW 15 Aug 2020) 
317

318

319

320

321

322

323

324

325

326

327

328

329

330

331

332

333

334

335

336

337

338

339

340

341

342

343

344

345

346

347

348

349

350

351

352

353

354

355

356

357

358

359

360

361

362

References

Alho CJR. 2011. Environmental effects of hydropower reservoirs on wild mammals and freshwater turtles in Amazonia: a review. Oecologia Australis 15:593-604.

https://doi.org/10.4257/oeco.2011.1503.11

Arraes DRS. 2012. Nidificação, neonatos e a influência da pressão antrópica em tracajá Podocnemis unifilis TROSCHEL, 1848 (Podocnemididae) na bacia do Rio Araguari, Amazônia Oriental, Brasil MSc Dissertation. Universidade Federal do Amapá. Available at http://www2.unifap.br/ppgbio/files/2010/05/D\%C3\%89BORA-ARRAESDISSERTA\%C3\%87\%C3\%830-NIDIFICA\%C3\%87\%C3\%830-NEONATOS-E-A-INFLUE.pdf laccessed 12 March 2016).

Balestra RAM. 2016. Manejo conservacionista e monitoramento populacional de quelônios amazônicos. Brasília:: Instituto Brasileiro do Meio Ambiente e dos Recursos Naturais Renováveis (Ibama). p 136.

Barichivich J, Gloor E, Peylin P, Brienen RJW, Schöngart J, Espinoza JC, and Pattnayak KC. 2018. Recent intensification of Amazon flooding extremes driven by strengthened Walker circulation. Science Advances 4:eaat8785. https://doi.org/10.1126/sciadv.aat8785

Batistella AM, and Vogt RC. 2008. Nesting Ecology of Podocnemis erythrocephala (Testudines, Podocnemididae) of the Rio Negro, Amazonas, Brazil. Chelonian Conservation and Biology 7:1220. https://doi.org/10.2744/CCB-0611.1

Beaupre S, Jacobson E, Lillywhite $\mathrm{H}$, and Zamudio K. 2004. Guidelines for use of live amphibians and reptiles in field and laboratory research. Herpetological Animal Care and Use Committee (HACC) of the American Society of Ichthyologists and Herpetologists. p 43.

Bodie JR. 2001. Stream and riparian management for freshwater turtles. Journal of Environmental Management 62:443-455. https://doi.org/10.1006/jema.2001.0454

Burke RL. 2015. Head-starting turtles: learning from experience. Herpetological Conservation and Biology 10:299-308.

Campos-Silva JV, Hawes JE, Andrade PC, and Peres CA. 2018. Unintended multispecies co-benefits of an Amazonian community-based conservation programme. Nature Sustainability 1:650. https://doi.org/10.1038/s41893-018-0170-5

Caputo FP, Canestrelli D, and Boitani L. 2005. Conserving the terecay (Podocnemis unifilis, Testudines: Pelomedusidae) through a community-based sustainable harvest of its eggs. Biological Conservation 126:84-92. https://doi.org/10.1016/j.biocon.2005.05.004

Castello L, McGrath DG, Hess LL, Coe MT, Lefebvre PA, Petry P, Macedo MN, Renó VF, and Arantes CC. 2013. The vulnerability of Amazon freshwater ecosystems. Conservation Letters 6:217-229. https://doi.org/10.1111/conl.12008

Danielsen F, Burgess ND, Balmford A, Donald PF, Funder M, Jones JPG, Alviola P, Balete DS, Blomley T, Brashares J, Child B, Enghoff M, Fjeldså J, Holt S, Hübertz H, Jensen AE, Jensen PM, Massao J, Mendoza MM, Ngaga Y, Poulsen MK, Rueda R, Sam M, Skielboe T, Stuart-Hill G, Topp-Jørgensen E, and Yonten D. 2009. Local Participation in Natural Resource Monitoring: a Characterization of Approaches. Conservation Biology 23:31-42. https://doi.org/10.1111/j.1523-1739.2008.01063.x

de Oliveira IAP, Norris D, and Michalski F. 2015. Anthropogenic and seasonal determinants of giant otter sightings along waterways in the northern Brazilian Amazon. Mammalian Biology - Zeitschrift für Säugetierkunde 80:39-46. https://doi.org/10.1016/j.mambio.2014.07.006

de Souza RR, and Vogt RC. 1994. Incubation Temperature Influences Sex and Hatchling Size in the Neotropical Turtle Podocnemis unifilis. Journal of Herpetology 28:453-464. https://doi.org/10.2307/1564958 
363

364

365

366

367

368

369

370

371

372

373

374

375

376

377

378

379

380

381

382

383

384

385

386

387

388

389

390

391

392

393

394

395

396

397

398

399

400

401

402

403

404

405

406

407

408
Deeming DC. 2018. Nesting environment may drive variation in eggshell structure and egg characteristics in the Testudinata. Journal of Experimental Zoology Part A: Ecological and Integrative Physiology 329:331-342. https://doi.org/10.1002/jez.2169

Eisemberg CC, Machado Balestra RA, Famelli S, Pereira FF, Diniz Bernardes VC, and Carl Vogt R. 2016. Vulnerability of Giant South American Turtle (Podocnemis expansa) nesting habitat to climatechange-induced alterations to fluvial cycles. Tropical Conservation Science 9:1940082916667139. https://doi.org/10.1177/1940082916667139

Escalona T, and Fa JE. 1998. Survival of nests of the terecay turtle (Podocnemis unifilis) in the NichareTawadu rivers, Venezuela. Journal of Zoology 244:303-312. https://doi.org/10.1111/j.14697998.1998.tb00034.x

Fagundes CK, Vogt RC, de Souza RA, and De Marco Jr P. 2018. Vulnerability of turtles to deforestation in the Brazilian Amazon: Indicating priority areas for conservation. Biological Conservation 226:300-310. https://doi.org/10.1016/j.biocon.2018.08.009

Ferreira Júnior PD, and Castro PdTA. 2006. Thermal Environment Characteristics of Podocnemis expansa and Podocnemis unifilis Nesting Areas on the Javaés River, Tocantins, Brazil. Chelonian Conservation and Biology 5:102-107. https://doi.org/10.2744/10718443(2006)5[102:TECOPE]2.0.CO;2

Ferreira Júnior PD, and Castro PTA. 2010. Nesting ecology of Podocnemis expansa (Schweigger, 1812) and Podocnemis unifilis (Troschel, 1848) (Testudines, Podocnemididae) in the Javaes River, Brazil. Brazilian Journal of Biology 70:85-94. http://dx.doi.org/10.1590/S151969842010000100012

Gallego-García N, and Castaño-Mora OV. 2008. Ecology and Status of the Magdalena River Turtle, Podocnemis lewyana, a Colombian Endemic. Chelonian Conservation and Biology 7:37-44. https://doi.org/10.2744/CCB-0643.1

Green AJ. 2001. Mass/length residuals: Measures of body condition or generators of spurious results? Ecology 82:1473-1483. https://doi.org/10.1890/0012-9658(2001)082[1473:MLRMOB]2.0.CO;2

Harju E, Sirén AH, and Salo M. 2018. Experiences from harvest-driven conservation: Management of Amazonian river turtles as a common-pool resource. Ambio 47:327-339. https://doi.org/10.1007/s13280-017-0943-5

Hirano LQL, Alves LdS, Menezes-Reis LT, Mendonça JdS, Simões K, Santos ALQ, and Vieira LG. 2019. Effects of egg exposure to atrazine and/or glyphosate on bone development in Podocnemis unifilis (Testudines, Podocnemididae). Ecotoxicology and Environmental Safety 182:109400. https://doi.org/10.1016/i.ecoenv.2019.109400

Iverson JB. 1991. Patterns of survivorship in turtles (Order Testudines). Canadian Journal of ZoologyRevue Canadienne De Zoologie 69:385-391. https://doi.org/10.1139/z91-060

Kennett R, Christian KA, and Pritchard D. 1993. Underwater Nesting by the Tropical Fresh-Water Turtle, Chelodina-Rugosa (Testudinata, Chelidae). Australian Journal of Zoology 41:47-52. https://doi.org/10.1071/ZO9930047

Kottek M, Grieser J, Beck C, Rudolf B, and Rubel F. 2006. World map of the Koppen-Geiger climate classification updated. Meteorologische Zeitschrift 15:259-263. https://doi.org/10.1127/09412948/2006/0130

Lees AC, Peres CA, Fearnside PM, Schneider M, and Zuanon JAS. 2016. Hydropower and the future of Amazonian biodiversity. Biodiversity and Conservation 25:451-466. https://doi.org/10.1007/s10531-016-1072-3

Lovich JE, Ennen JR, Agha M, and Gibbons JW. 2018. Where Have All the Turtles Gone, and Why Does It Matter? BioScience 68:771-781. https://doi.org/10.1093/biosci/biy095

Peer) reviewing PDF | (2020:05:49421:2:0:NEW 15 Aug 2020) 
409

410

411

412

413

414

415

416

417

418

419

420

421

422

423

424

425

426

427

428

429

430

431

432

433

434

435

436

437

438

439

440

441

442

443

444

445

446

447

448

449

450

451

452

453

454

455

456

Marengo JA, and Espinoza JC. 2016. Extreme seasonal droughts and floods in Amazonia: causes, trends and impacts. International Journal of Climatology 36:1033-1050.

https://doi.org/10.1002/joc.4420

Michalski F, Norris D, Quintana I, Valerio A, and Gibbs JP. 2020. Substrate influences human removal of freshwater turtle nests in the eastern Brazilian Amazon. Scientific Reports 10:8082. https://doi.org/10.1038/s41598-020-65074-1

Norris D, and Michalski F. 2013. Socio-economic and spatial determinants of anthropogenic predation on Yellow-spotted River Turtle, Podocnemis unifilis (Testudines: Pelomedusidae), nests in the Brazilian Amazon: Implications for sustainable conservation and management. Zoologia (Curitiba) 30:482-490. https://doi.org/10.1590/S1984-46702013000500003

Norris D, Michalski F, and Gibbs JP. 2018a. Beyond harm's reach? Submersion of river turtle nesting areas and implications for restoration actions after Amazon hydropower development. PeerJ 6:e4228. https://doi.org/10.7717/peerj.4228

Norris D, Michalski F, and Gibbs JP. 2018b. Community involvement works where enforcement fails: conservation success through community-based management of Amazon river turtle nests. PeerJ 6:e4856. https://doi.org/10.7717/peerj.4856

Norris D, Peres CA, Michalski F, and Gibbs JP. 2019. Prospects for freshwater turtle population recovery are catalyzed by pan-Amazonian community-based management. Biological Conservation 233:51-60. https://doi.org/10.1016/j.biocon.2019.02.022

Packard MJ, Packard GC, and Boardman TJ. 1982. Structure of Eggshells and Water Relations of Reptilian Eggs. Herpetologica 38:136-155.

Páez V, and Bock B. 1998. Temperature effect on incubation period in the yellow-spotted river turtle, Podocnemis unifilis, in the Colombian Amazon. Chelonian Conservation and Biology 3:31-36.

Páez VP, and Bock BC. 2004. Pre-and post-hatching factors affecting juvenile growth rates in the yellowspotted river turtle (Podocnemis unifilis). Actualidades Biológicas 26:137-151.

Páez VP, Lipman A, Bock BC, and Heppell SS. 2015. A plea to redirect and evaluate conservation programs for South America's Podocnemidid River Turtles. Chelonian Conservation and Biology 14:205-216. https://doi.org/10.2744/CCB-1122.1

Paredes OSL, Norris D, de Oliveira TG, and Michalski F. 2017. Water availability not fruitfall modulates the dry season distribution of frugivorous terrestrial vertebrates in a lowland Amazon forest. PloS one 12:e0174049. https://doi.org/10.1371/journal.pone.0174049

Peig J, and Green AJ. 2010. The paradigm of body condition: a critical reappraisal of current methods based on mass and length. Functional Ecology 24:1323-1332. https://doi.org/10.1111/j.13652435.2010.01751.x

Pignati MT, Fernandes LF, Miorando PS, Ferreira PD, and Pezzuti JCB. 2013. Nesting Site and Hatching Success of Podocnemis unifilis (Testudines: Podocnemididae) in a Floodplain Area in Lower Amazon River, Pará, Brazil. South American Journal of Herpetology 8:175-185. https://doi.org/10.2994/SAJH-D-13-00006.1

Quintana I, Norris D, Valerio A, Becker FG, Gibbs JP, and Michalski F. 2019. Nest removal by humans creates an evolutionary trap for Amazonian freshwater turtles. Journal of Zoology 309:94-105. https://doi.org/10.1111/jzo.12689

R Development Core Team. 2020. R: A language and environment for statistical computing. 3.6.3. Available at https://www.R-project.org/.

Rachmansah A, Norris D, and Gibbs JP. 2020. Population dynamics and biological feasibility of sustainable harvesting as a conservation strategy for tropical and temperate freshwater turtles. PloS one 15:e0229689. https://doi.org/10.1371/journal.pone.0229689

Rhodin AGJ, Stanford CB, van Dijk PP, Eisemberg C, Luiselli L, Mittermeier RA, Hudson R, Horne BD, Goode EV, Kuchling G, Walde A, Baard EHW, Berry KH, Bertolero A, Blanck TEG, Bour R,

Peer] reviewing PDF | (2020:05:49421:2:0:NEW 15 Aug 2020) 
Buhlmann KA, Cayot L, Collett S, Currylow A, Das I, Diagne T, Ennen JR, Forero-Medina G, Frankel MG, Fritz U, García G, Gibbons JW, Gibbons PM, Shiping G, Guntoro J, Hofmeyr MD, Iverson JB, Kiester AR, Lau M, Lawson DP, Lovich JE, Moll EO, Páez VP, Palomo-Ramos R, Platt K, Platt SG, Pritchard PCH, Quinn HR, Rahman SC, Randrianjafizanaka ST, Schaffer J, Selman W, Shaffer HB, Sharma DSK, Haitao S, Singh S, Spencer R, Stannard K, Sutcliffe S, Thomson S, and Vogt RC. 2018. Global Conservation Status of Turtles and Tortoises (Order Testudines). Chelonian Conservation and Biology 17:135-161. https://doi.org/10.2744/CCB-1348.1

Semlitsch RD, and Bodie JR. 2003. Biological Criteria for Buffer Zones around Wetlands and Riparian Habitats for Amphibians and Reptiles. Conservation Biology 17:1219-1228. https://doi.org/10.1046/i.1523-1739.2003.02177.x

Sinovas $\mathrm{P}$, Price $\mathrm{B}$, King $\mathrm{E}$, Hinsley $\mathrm{A}$, and Pavitt A. 2017. Wildlife trade in the Amazon countries: an analysis of trade in CITES listed species. Cambridge, UK: Technical report prepared for the Amazon Regional Program. Available at https://www.unep-wcmc.org/resources-anddata/wildlife-trade-in-amazon-countries--an-analysis-of-trade-in-cites-listed-species.

Smith NJH. 1979. Aquatic turtles of Amazonia: an endangered resource. Biological Conservation:165176. https://doi.org/10.1016/0006-3207(79)90019-3

Soini P. 1995. Estudio y manejo de quelonios acuáticos, 1987. Informe № 26. Reporte Pacaya-Samiria Investigaciones en Cahuana 1994:279-287.

Steen DA, Gibbs JP, Buhlmann KA, Carr JL, Compton BW, Congdon JD, Doody JS, Godwin JC, Holcomb KL, Jackson DR, Janzen FJ, Johnson G, Jones MT, Lamer JT, Langen TA, Plummer MV, Rowe JW, Saumure RA, Tucker JK, and Wilson DS. 2012. Terrestrial habitat requirements of nesting freshwater turtles. Biological Conservation 150:121-128. https://doi.org/10.1016/i.biocon.2012.03.012

Vogt RC, and Pezzutti JCB. 1999. Nesting ecology of Podocnemis sextuberculata (Testudines, Pelomedusidae) in the Japurá River, Amazonas, Brazil. Chelonian Conservation and Biology 3:419-424.

Winkler JD. 2006. Testing phylogenetic implications of eggshell characters in side-necked turtles (Testudines: Pleurodira). Zoology 109:127-136. https://doi.org/10.1016/j.zool.2005.12.003

Winkler JD, and Sánchez-Villagra MR. 2006. A nesting site and egg morphology of a Miocene turtle from Urumaco, Venezuela: Evidence of marine adaptations in Pelomedusoides. Palaeontology 49:641-646. https://doi.org/10.1111/j.1475-4983.2006.00557.x

Wood SN. 2011. Fast stable restricted maximum likelihood and marginal likelihood estimation of semiparametric generalized linear models. Journal of the Royal Statistical Society: Series $B$ (Statistical Methodology) 73:3-36. https://doi.org/10.1111/j.1467-9868.2010.00749.x

Wood SN. 2017. Generalized additive models: an introduction with R: Chapman and Hall/CRC. 


\section{Table 1 (on next page)}

Characteristics of saved nests along the Araguari river basin.

Summary of Podocnemis unifilis nesting areas submersed due to flooding along two rivers. 
1

\begin{tabular}{|c|c|c|c|c|c|c|}
\hline \multirow[b]{2}{*}{ River } & \multirow[b]{2}{*}{$\mathrm{km}$} & \multicolumn{2}{|c|}{ Count (areas/nests) } & \multicolumn{3}{|c|}{ Saved nest characteristics } \\
\hline & & aTotal & Saved & $\begin{array}{l}\text { b Height above } \\
\text { water }(\mathrm{m})\end{array}$ & Age (days) & $\begin{array}{l}\text { Submersion time } \\
\text { (days) }\end{array}$ \\
\hline Araguari & 46.4 & $5 / 37$ & $5 / 33$ & $0.75(0.05-1.10)$ & $39.1(35-70)$ & $0.9(0-2)$ \\
\hline Falsino & 28.2 & $24 / 123$ & $11 / 41$ & $1.30(0.35-1.79)$ & $45.7(38-72)$ & $1.3(0-2)$ \\
\hline Overall & 74.6 & $29 / 160$ & $16 / 74$ & $0.91(0.05-1.79)$ & $42.4(35-72)$ & $1.1(0-2)$ \\
\hline
\end{tabular}

2 a Total of monitored nesting areas with nests at the time of flooding. This total excludes nests

3 recorded as predated, harvested or hatched prior to water level rising (26 November 2018).

$4 \quad \mathrm{~b}$ Height above river water level at time of nesting, mean values with minimum and maximum in

5 parentheses.

6

7 


\section{Table 2 (on next page)}

Egg and hatchling survival.

Survival of eggs and premature hatchlings recovered from 74 submersed Podocnemis unifilis nests along the Araguari river basin. 


\begin{tabular}{ccccccc}
\hline River & Eggs & Egg survival & \multicolumn{2}{c}{ Hatchlings Hatchling survival } & \multicolumn{2}{c}{ Hatchlings released } \\
& saved & & saved & Count & Weight ${ }^{\mathrm{a}}(\mathrm{g})$ \\
\hline Araguari & 388 & $59.0 \%(229 / 388)$ & 11 & $94.6 \%(227 / 240)$ & 227 & $17.6(9.8-23.2)$ \\
Falsino & 538 & $63.6 \%(342 / 538)$ & 54 & $93.9 \%(372 / 396)$ & 372 & $18.2(11.1-21.6)$ \\
Total & 926 & $61.7 \%(571 / 926)$ & 65 & $94.2 \%(599 / 636)$ & 599 & $18.0(9.8-23.2)$
\end{tabular}

1 Weight values from 409 (68\%) of the 599 released hatchlings (145 and 264 from Araguari and Falsino 2 rivers, respectively). 
Figure 1

Study area.

(A) State of Amapá in Brazil. (B) Location of the study area, and protected areas (FLONA and FLOTA) within Amapá. (C) Location of 16 Podocnemis unifilis nesting areas where 74 nests were recovered after submersion (filled orange circles sized in proportion to the number of recovered eggs). Location of the nearest town (Porto Grande) is shown by a black square.

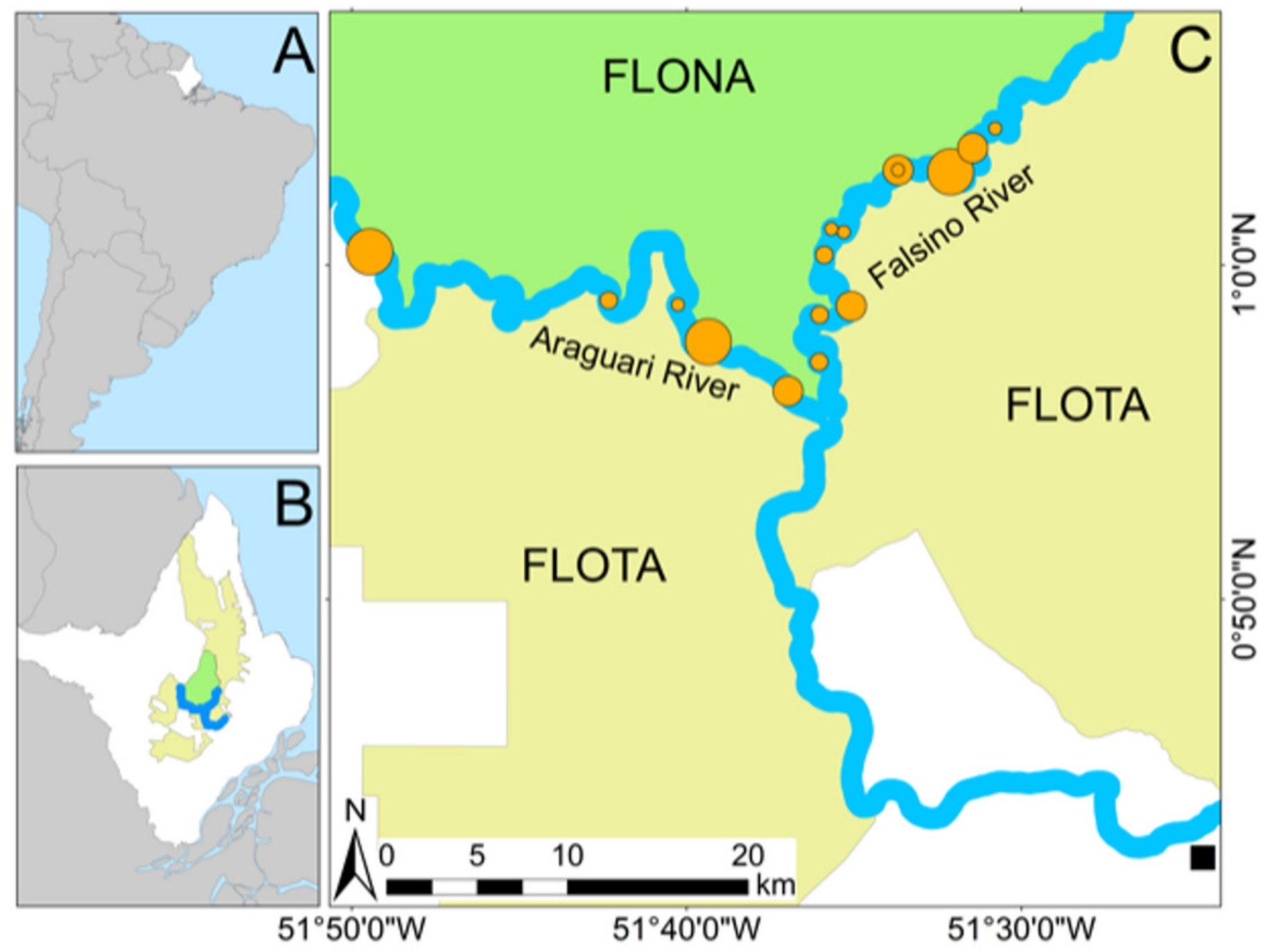




\section{Figure 2}

Rapid river level rise.

Illustrating increase in river water level between 9 November and 15 December 2018. (A) Daily river level values (black points) and blue line illustrating trend. Horizontal shaded area spans levels at which 74 Podocnemis unifilis nests were submerged, showing levels corresponding to minimum and maximum nest heights (black dashed lines) and mean nest height (solid horizontal black line). Horizontal grey dashed line shows Y-axis reference river level [the minimum value $(282 \mathrm{~cm}$ ) recorded since records started (22 March 1981)] (B) Riverside photos of one of the highest nesting areas showing changes in river level. Yellow arrows indicate location of the same tree trunk as a reference point. 


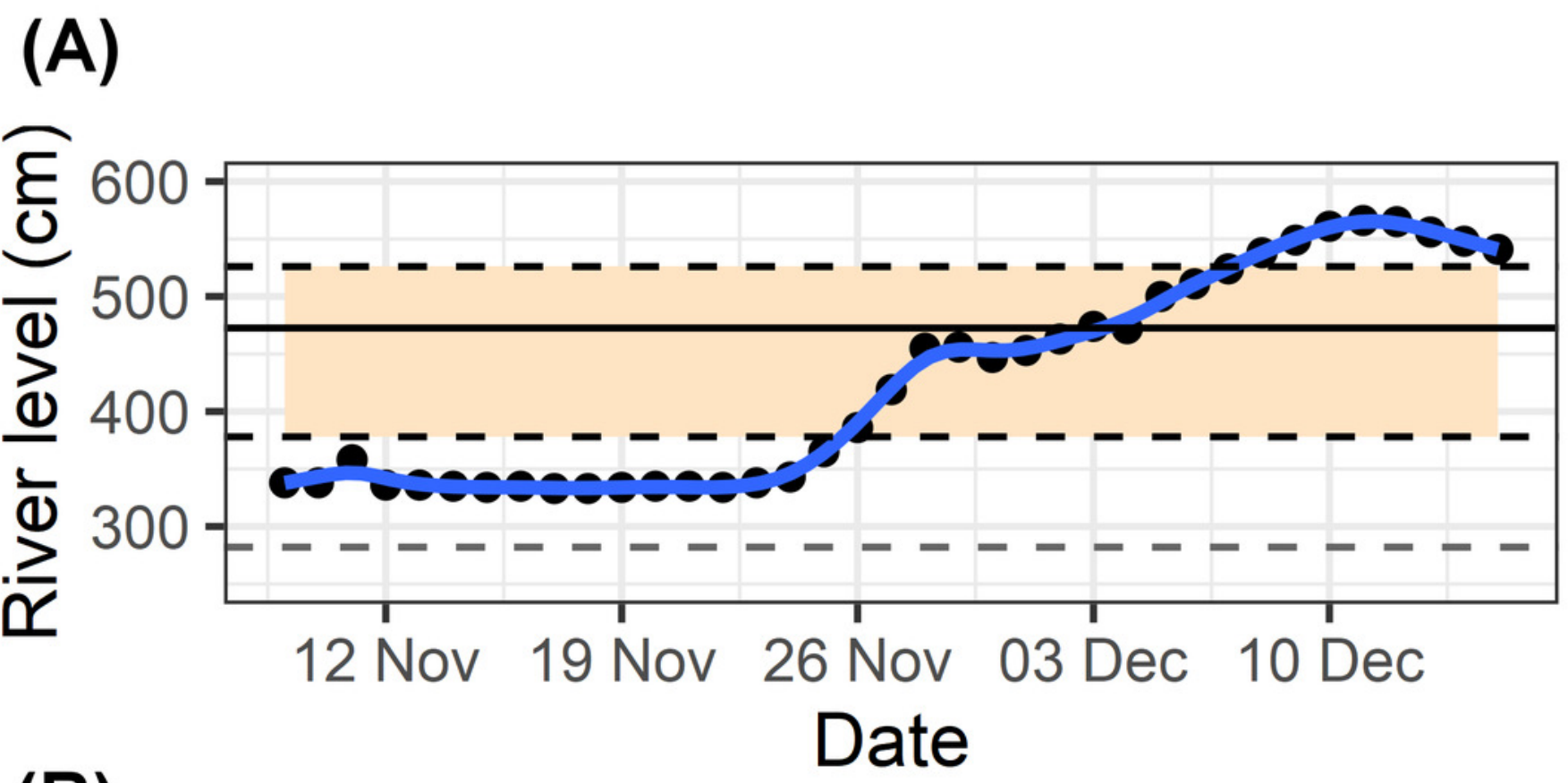

(B)
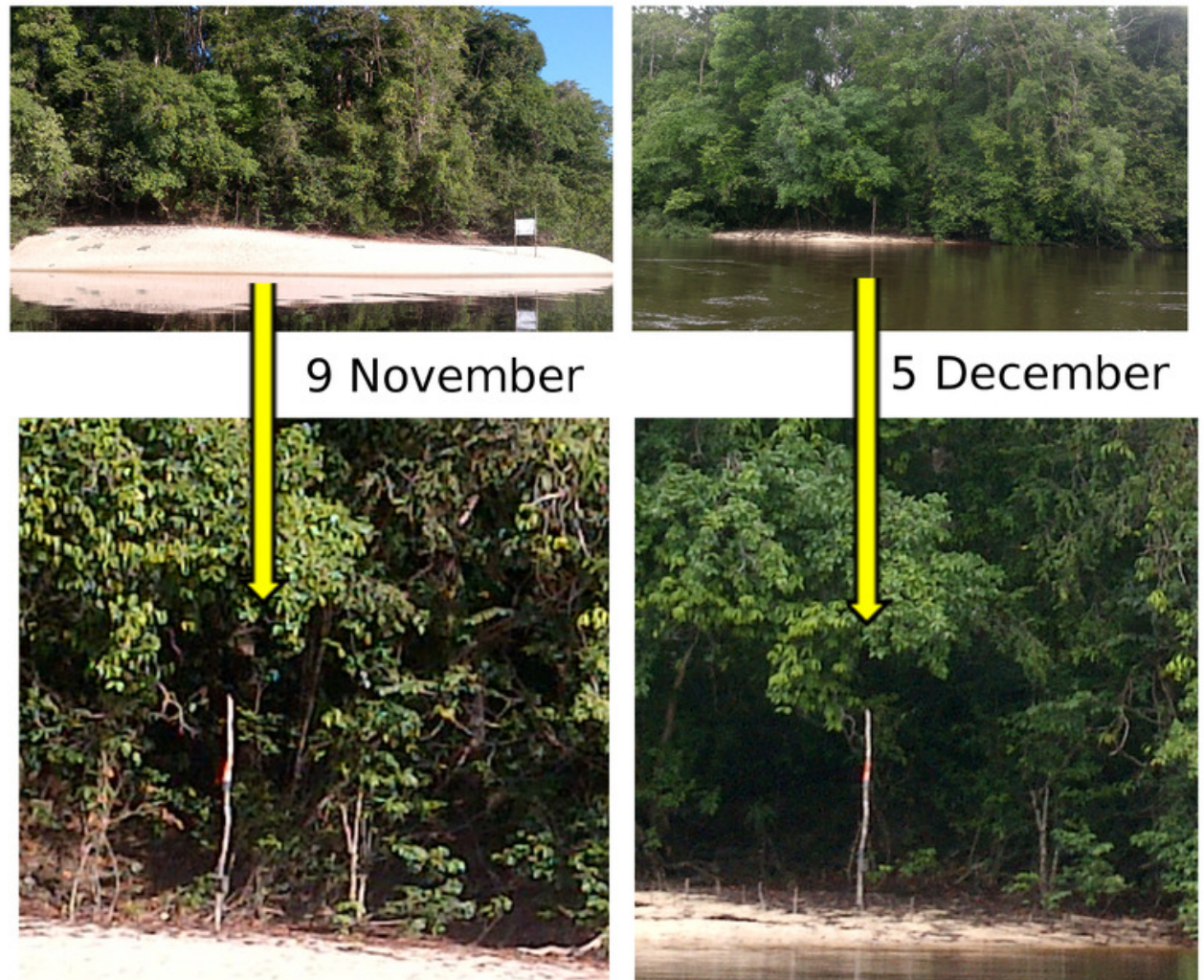
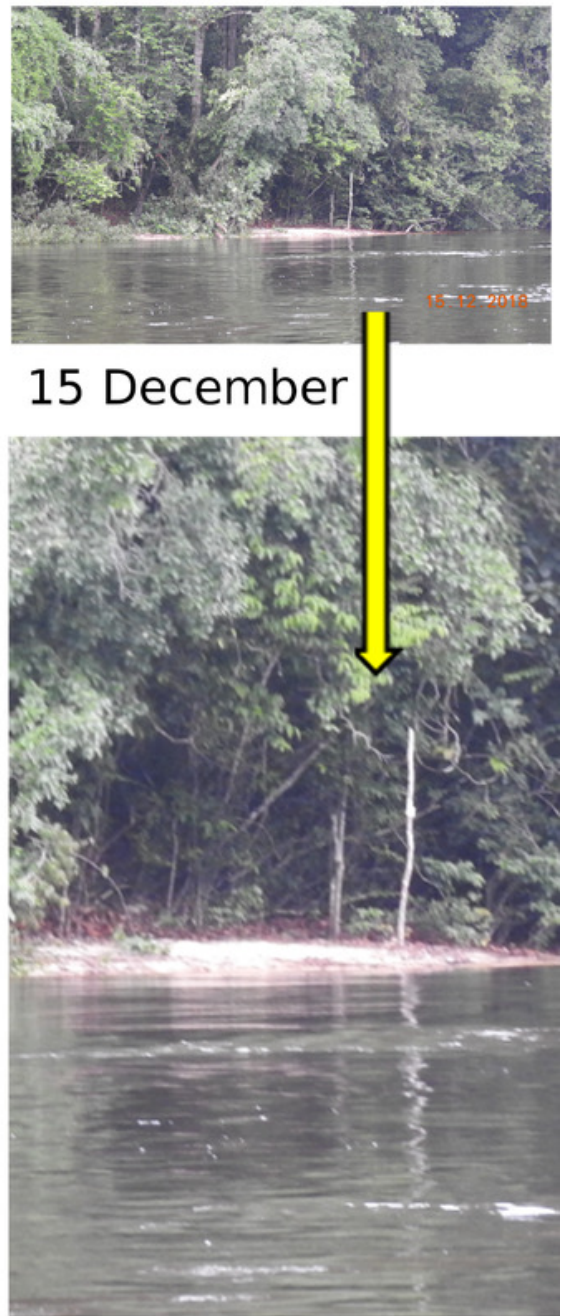
Figure 3

Community-based rearing.

Illustrated schematic showing the steps taken to rear Podocnemis unifilis eggs and hatchlings submerged by rapid river level rise along $75 \mathrm{~km}$ of rivers in the eastern Brazilian Amazon. 


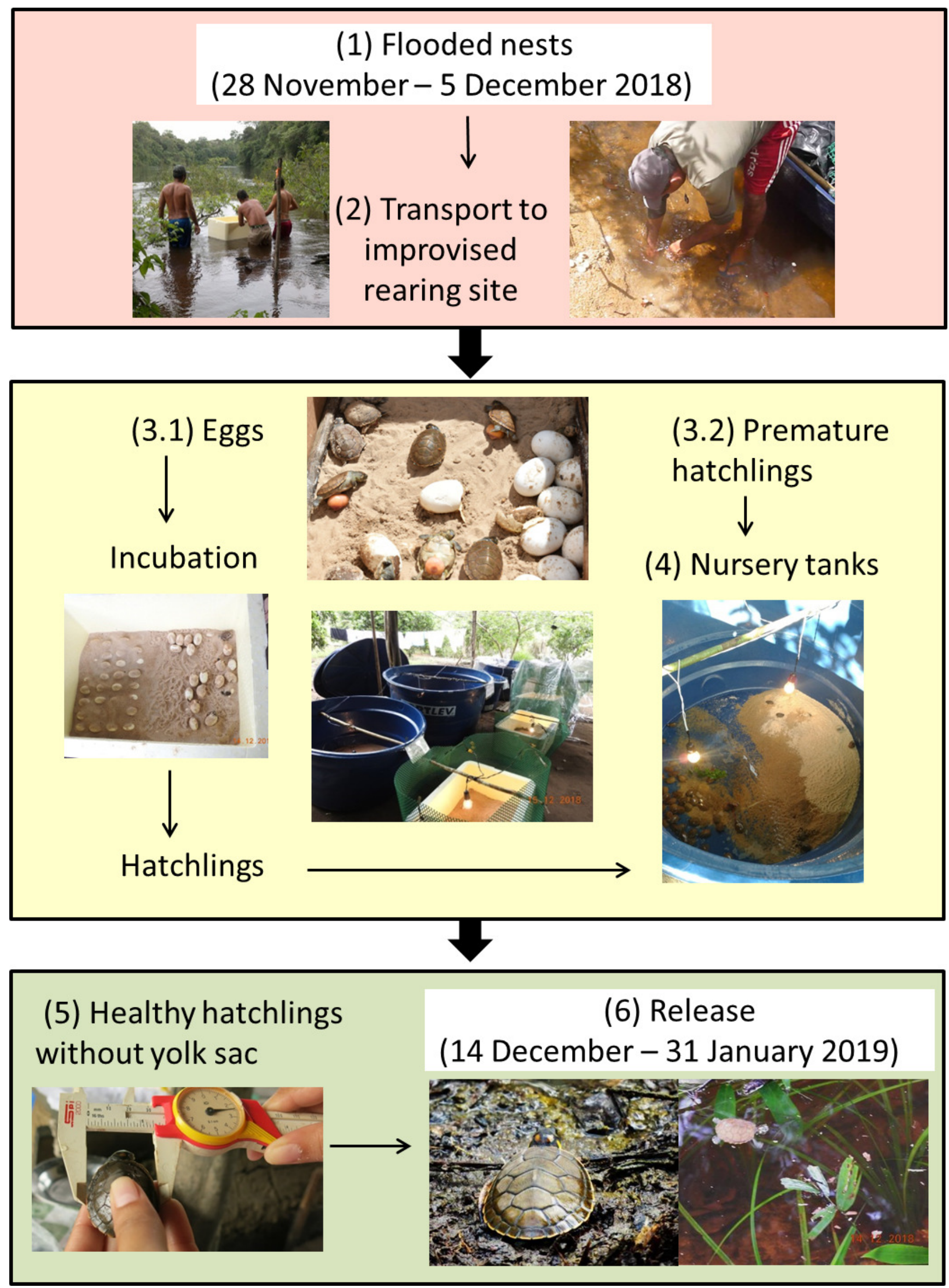




\section{Figure 4}

Hatchling condition.

Body size relationships (" $A$ " and " $C$ ") and residual body condition indexes (" $B$ " and " $D$ ") for Podocnemis unifilis hatchlings released after nest submersion. Body size relationships (" $\mathrm{A}$ " and " $\mathrm{C}$ ") show untransformed values with GAM model trend line to aid visual interpretation. Shaded points show values of from Araguari (red) and Falsino (blue) river hatchlings. Residual body condition indexes (" $\mathrm{B}$ " and " $\mathrm{D}$ ") compared between hatchlings from Araguari and Falsino rivers. GAM condition index is the residuals obtained from modelling the response of In transformed body mass predicted by two body size indicators (B) In straightline carapace length (GAM R ${ }_{\text {adj }}^{2}=0.864$, Deviance explained $\left.=86.6 \%\right)$ and $(D)$ In carapace area $\left(G A M R_{\text {adj }}^{2}=0.878\right.$, Deviance explained $\left.=88.0 \%\right)$. Violin-plots show density distribution of values, and colored boxplots show median values and the lower and upper hinges corresponding to the first and third quartiles (25th and 75th percentiles). 
(A)

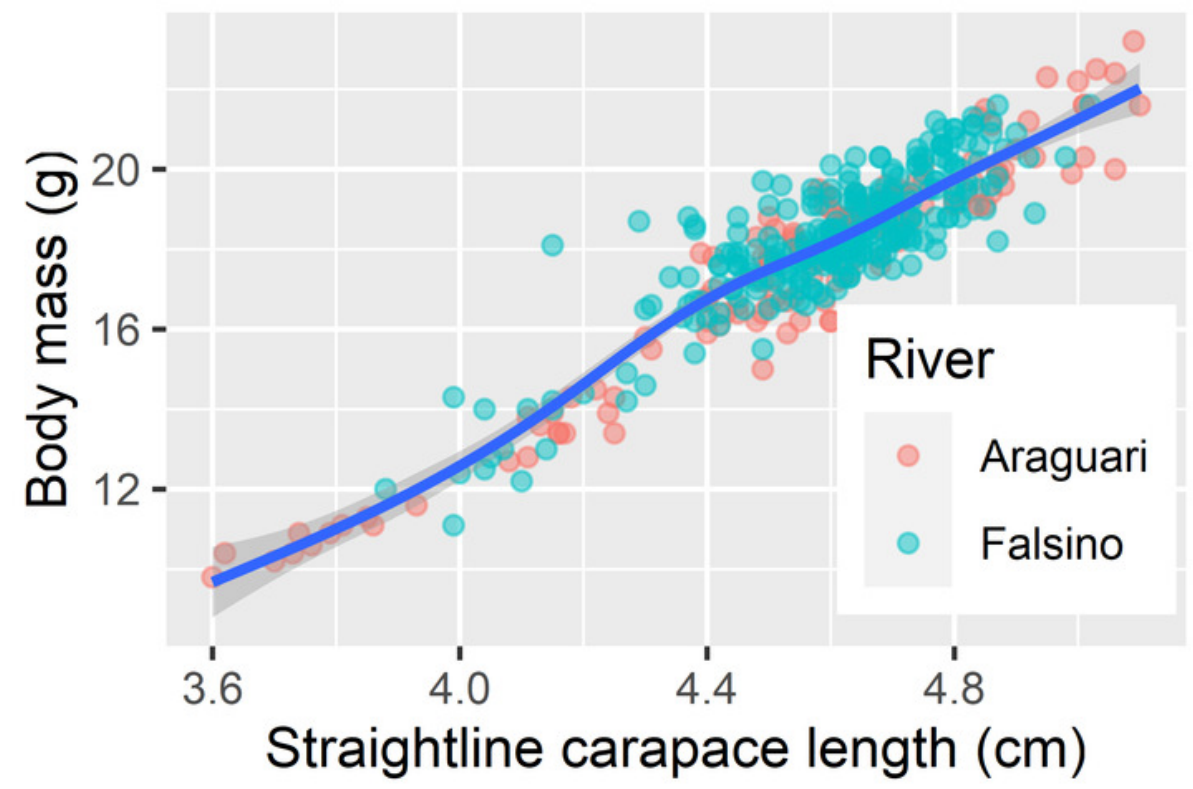

(C)

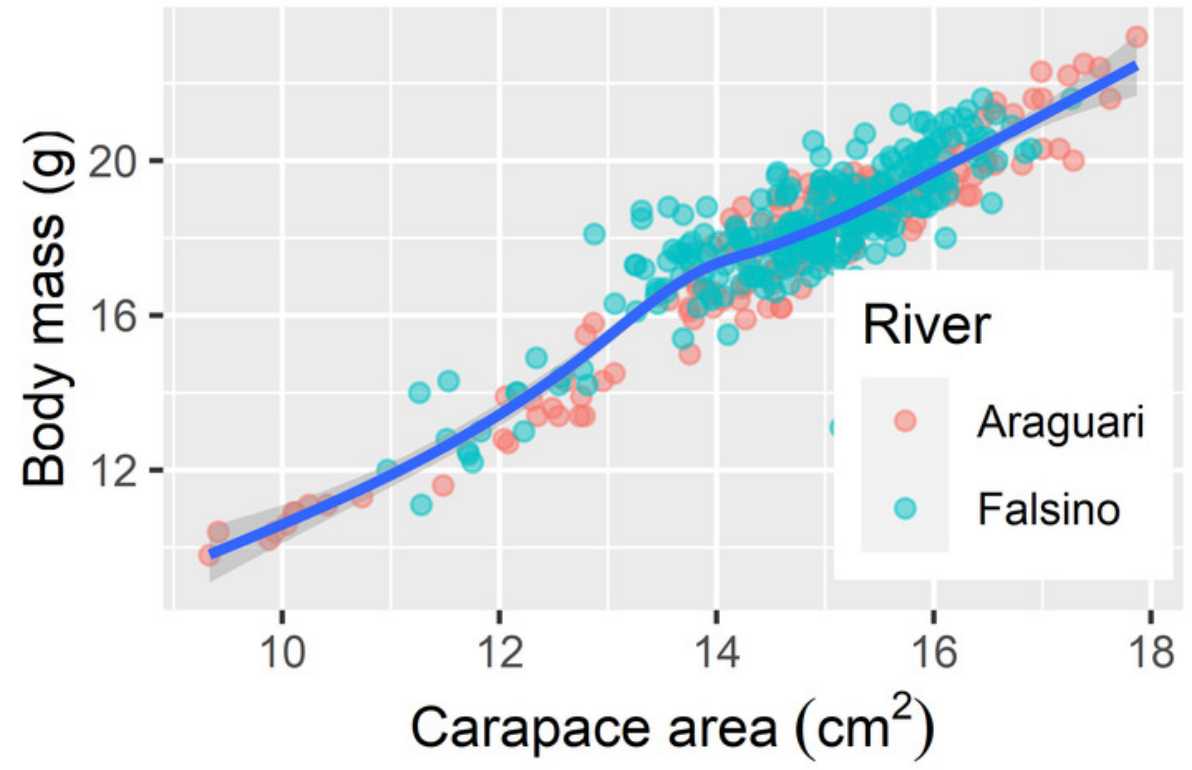

(B)

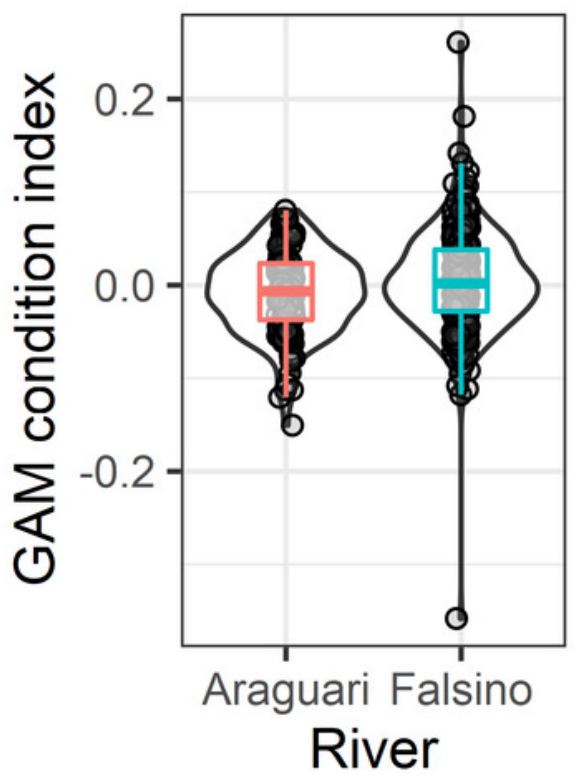

(D)

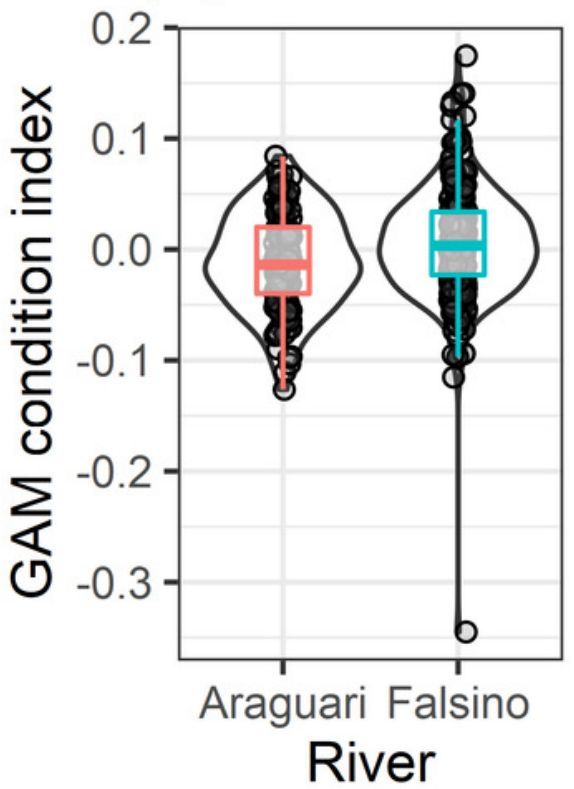

